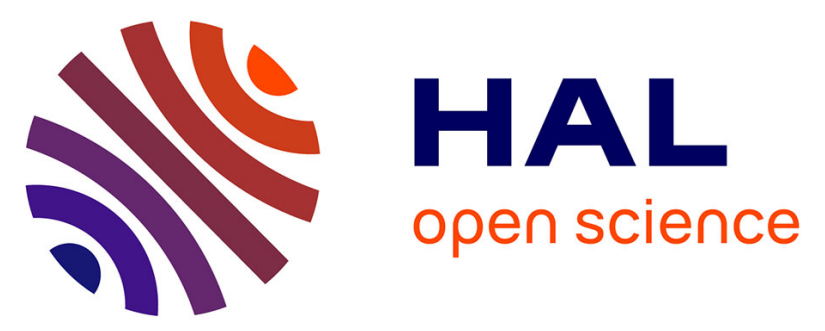

\title{
A combined Langmuir Probe - fluxgate magnetometer sensor design for Comet Interceptor
}

Johan de Keyser, Sylvain Ranvier, Jeroen Maes, Jordan Pawlak, Eddy Neefs, Frederik Dhooghe, Uli Auster, Bernd Chares, Niklas Edberg, Jesper Fredriksson, et al.

\section{To cite this version:}

Johan de Keyser, Sylvain Ranvier, Jeroen Maes, Jordan Pawlak, Eddy Neefs, et al.. A combined Langmuir Probe - fluxgate magnetometer sensor design for Comet Interceptor. vEGU21, 2021, online, France. 10.5194/egusphere-egu21-7197 . insu-03559375

\section{HAL Id: insu-03559375 https://hal-insu.archives-ouvertes.fr/insu-03559375}

Submitted on 7 Feb 2022

HAL is a multi-disciplinary open access archive for the deposit and dissemination of scientific research documents, whether they are published or not. The documents may come from teaching and research institutions in France or abroad, or from public or private research centers.
L'archive ouverte pluridisciplinaire HAL, est destinée au dépôt et à la diffusion de documents scientifiques de niveau recherche, publiés ou non, émanant des établissements d'enseignement et de recherche français ou étrangers, des laboratoires publics ou privés. 


\title{
EGU21-7197
}

https://doi.org/10.5194/egusphere-egu21-7197

EGU General Assembly 2021

(c) Author(s) 2022. This work is distributed under

the Creative Commons Attribution 4.0 License.

\section{A combined Langmuir Probe - fluxgate magnetometer sensor design for Comet Interceptor}

\author{
Johan De Keyser ${ }^{1}$, Sylvain Ranvier ${ }^{1}$, Jeroen Maes ${ }^{1}$, Jordan Pawlak ${ }^{1}$, Eddy Neefs ${ }^{1}$, Frederik \\ Dhooghe $^{1}$, Uli Auster ${ }^{2}$, Bernd Chares ${ }^{2}$, Niklas Edberg ${ }^{3}$, Jesper Fredriksson ${ }^{3}$, Anders Eriksson ${ }^{3}$, Pierre \\ Henri $^{4}$, Olivier Le Duff ${ }^{4}$, and Joakim Peterson ${ }^{5}$ \\ ${ }^{1}$ Royal Belgian Institute for Space Aeronomy, Space Physics, Brussels, Belgium (johan.dekeyser@aeronomie.be) \\ ${ }^{2}$ Technische Universität Braunschweig, Germany \\ ${ }^{3}$ Institutet for Rymdfysik, Uppsala, Sweden \\ ${ }^{4} \mathrm{LPC} 2 \mathrm{E}$, Orléans, France \\ ${ }^{5}$ Institutet for Rymdfysik, Kiruna, Sweden
}

The in situ characterization of space plasmas requires an instrument suite for the measurement of the magnetic and electric fields and waves and of the plasma populations, with the field instruments typically being mounted on booms. This can be a tall order, especially for small planetary science missions, so that one has to seek simplifications. In the context of the Comet Interceptor mission, we have designed a combined sensor that consists of a hollow spherical Langmuir probe that harbors a fluxgate magnetometer at its center. Special precautions have been taken to minimize the possible interference between both, while at the same time being very lightweight. An engineering model has been built and is tested and characterized in detail. Such a combined sensor, together with a companion Langmuir probe, provides data regarding magnetic and electric fields and waves, total ion and electron densities and electron temperature, as well as the ambient nanodust population. It can form the core of an in situ plasma characterization package and offers reference data for the other sensors, such as magnetic field direction, spacecraft potential and total plasma density at high cadence. 